\begin{tabular}{c} 
Kementerian \\
Perindustrian \\
$\begin{array}{c}\text { REPUBLIK INDONESIA } \\
\text { http://ejournal.kemenperin.go.id/jli }\end{array}$ \\
\hline Jurnal Litbang Industri \\
\hline
\end{tabular}

\title{
Pengaruh penambahan natrium tetra boraks untuk pengawetan limbah batang kelapa sawit
}

\section{The effect of adding sodium tetra borax for preserving of palm oil stems waste}

\author{
A Ardinal*, Salamariza, Sy, dan S Sofyan \\ Balai Riset dan Standardisasi Industri Padang \\ J1. Raya LIK No. 23 Ulu Gadut, Padang, Indonesia \\ *e-mail: ardinal_ok@yahoo.co.id
}

\begin{tabular}{l}
\hline INFO ARTIKEL \\
\hline Sejarah artikel: \\
Diterima: \\
29 April 2021 \\
Direvisi: \\
24 Juni 2021 \\
Diterbitkan: \\
30 Juni 2021
\end{tabular}

\section{Kata kunci:}

replanting;

batang kelapa sawit; limbah kayu sawit; natrium tetra boraks; pengawetan \begin{abstract}
ABSTRAK
Luas areal perkebunan kelapa sawit di Indonesia saat ini kurang lebih 11 juta hektar. Selain menghasilkan buah kelapa sawit yang melimpah, kebun sawit ini juga menghasilkan limbah replanting berupa batang kelapa sawit pada saat dilakukan regenerasi kebun. Tujuan dari penelitian ini adalah pengawetan limbah replanting batang kelapa sawit dengan natrium tetra boraks $\left(\mathrm{Na}_{2} \mathrm{~B}_{3} \mathrm{O}_{4}\right)$. Perlakuan yang dilakukan yaitu dengan memvariasikan bagian batang sawit (kayu bagian dalam dan bagian luar batang sawit). Konsentrasi pengawet natrium tetra boraks yaitu 1; 2,5 dan 5\% dengan waktu perendaman 2, 4, dan 6 hari. Dari analisis awal limbah kayu bagian dalam sebelum pengawetan diperoleh rata-rata kadar air $35,1 \%$, kuat lentur $26,48 \mathrm{~kg} / \mathrm{cm}^{2}$, kuat tekan $3,73 \mathrm{~kg} / \mathrm{cm}^{2}$, dan kerapatan $0,19 \mathrm{~g} / \mathrm{cm}^{3}$. Sedangkan kayu bagian luar sebelum pengawetan memiliki rata-rata kadar air $25,5 \%$, kuat lentur $32,16 \mathrm{~kg} / \mathrm{cm}^{2}$, kuat tekan $5,47 \mathrm{~kg} / \mathrm{cm}^{2}$, dan kerapatan $0,25 \mathrm{~g} / \mathrm{cm}^{3}$. Perlakuan terbaik diperoleh pada kayu bagian luar dengan perendaman selama 4 hari dan konsentrasi natrium tetra boraks 2,5\%. Setelah dilakukan pengawetan terjadi peningkatan kuat tekan, kuat lentur, dan kerapatan. Kayu perlakuan terbaik memiliki rata-rata kuat lentur $44,71 \mathrm{~kg} / \mathrm{cm}^{2}$, kuat tekan $6,47 \mathrm{~kg} / \mathrm{cm}^{2}$, dan kerapatan $0,30 \mathrm{~g} / \mathrm{cm}^{3}$. Kadar air rata-rata menurun setelah proses pengeringan menjadi $8,25 \%$. Kayu hasil pengawetan dapat digunakan untuk membuat produk asesoris dan produk furniture lainnya.
\end{abstract}

Keywords:
replanting;
palm oil trunk;
palm oil wood waste;
sodium tetra borax;
preservation

\begin{abstract}
Currently, the total area of oil palm plantations in Indonesia is approximately 11 million hectares. In addition to producing abundant of oil palm, this oil palm plantation also produces replanting waste in the form of oil palm stems when the plantation is regenerated. The purpose of this study was to preserve oil palm stem replanting waste with sodium tetra borax $\left(\mathrm{Na}_{2} \mathrm{~B}_{3} \mathrm{O}_{4}\right)$. The treatment was carried out by varying the parts of the palm trunk (the inner part and the outer part wood of the palm trunk). The concentration of sodium tetra borax preservative were 1; 2,5 and 5\% with immersion time of 2, 4, and 6 days. From the initial analysis of the inner part wood waste before preservation, it was found that the average moisture content, the flexural strength, the compressive strength, and the density was $35.1 \%, 26.48 \mathrm{~kg} / \mathrm{cm}^{2}, 3.73 \mathrm{~kg} / \mathrm{cm}^{2}, 0.19$ $\mathrm{g} / \mathrm{cm}^{3}$ respectively. While the outer part wood before preservation has an average moisture content of $25.5 \%$, flexural strength of $32.16 \mathrm{~kg} / \mathrm{cm}^{2}$, compressive strength of $5.47 \mathrm{~kg} / \mathrm{cm}^{2}$, and density of $0.25 \mathrm{~g} / \mathrm{cm}^{3}$. The best treatment was obtained on the outer wood with immersion for 4 days and a concentration of $2.5 \%$ sodium tetra borax. After preservation there was an increase in compressive strength, flexural strength, and density. The best treated wood has an average flexural strength of $44.71 \mathrm{~kg} / \mathrm{cm}^{2}$, compressive strength of $6.47 \mathrm{~kg} / \mathrm{cm}^{2}$, and a density of $0.30 \mathrm{~g} / \mathrm{cm}^{3}$. The average water content decreased after drying to $8.25 \%$. Preserved wood can be used to make accessories and other furniture products.
\end{abstract}

C 2021 Penulis. Dipublikasikan oleh Baristand Industri Padang. Akses terbuka dibawah lisensi CC BY-NC-SA 


\section{Pendahuluan}

Indonesia dan Malaysia merupakan dua negara pensuplai $85 \%$ kebutuhan minyak sawit dunia dengan jumlah sekitar 53.500 juta ton. Perkebunan sawit telah menyebar hingga 22 propinsi yang ada di Indonesia. Luas areal perkebunan sawit di Indonesia pada tahun 2017 mencapai 12,2 juta hektar (Perkebunan, 2017).

Dari sebaran perkebunan kelapa sawit tersebut termasuk Sumatera Barat dengan luas perkebunan kelapa sawit saat ini 350 ribu Hektar yang tersebar di beberapa kabupaten. Tanaman kelapa sawit menghasilkan tandan buah segar (TBS). Tandan buah segar akan menghasilkan minyak sawit kasar yang disebut Crude Palm Oil (CPO) setelah diolah. Namun tanaman kelapa sawit menghasilkan tandan buah segar hanya sampai umur 25 tahun, setelah itu harus dilakukan penanaman kembali (replanting) untuk peremajaan. Hasil replanting akan menghasilkan limbah batang kelapa sawit. Replanting pohon kelapa sawit di Sumatera Barat rata-rata 25.000 hektar/tahun dan biasanya kayu kelapa sawit yang direplanting ini dibiarkan membusuk dimakan rayap dan akibatnya dapat menggangu lingkungan sekitar perkebunan. Selama ini kayu sawit hasil replanting kelapa sawit belum dimanfaatkan. Hal ini disebabkan kualitas kayu kelapa sawit yang rendah dan kandungan kadar air sangat tinggi (Siregar, 2011).

Karena jumlah kayu kelapa sawit hasil replanting cukup banyak maka perlu dipikirkan upaya-upaya agar tidak menimbulkan permasalahan. Salah satu cara yang dapat dilakukan adalah melakukan pengawetan untuk meningkatkan kualitas kayu sehingga dapat dijadikan sebagai bahan baku untuk pembuatan meubel (furniture), bahan baku asesoris, interior dan bahan baku produk kerajinan, secara tidak lansung dapat mengurangi pemakaian kayu dari hutan serta dapat meningkatkan kesempatan berusaha bagi penduduk sekitar perkebunan.

Limbah padat dan cair dari industri kelapa sawit memiliki potensi yang sangat baik untuk dikembangkan. Beberapa aplikasi teknologi sederhana sudah ada yang berhasil cukup baik, namun sebenarnya jika dilakukan upgrade teknologi, limbah-limbah tersebut bisa menghasilkan produk yang bernilai lebih tinggi lagi (Kamal, 2012). Sebagai contoh, di beberapa industri, limbah POME (Palm Oil Mill Effluent) yang ditreatment lebih dulu digunakan sebagai pupuk untuk perkebunan. POME ini jika dikonversi menjadi biogas maka nilai tambahnya akan lebih tinggi.

Tandan kosong yang selama ini hanya digunakan sebagai mulsa (material penutup tanaman budidaya yang dimaksudkan untuk menjaga kelembaban tanah serta menekan pertumbuhan gulma dan penyakit sehingga membuat tanaman tersebut tumbuh dengan baik) dan juga pupuk akan meningkatkan nilainya jika diproses menjadi komposit, fiber untuk bahan bangunan, dan lain sebagainya. Batang dari tanaman sawit yang sudah tidak terpakai, akan menjadi limbah dan merupakan massa terbesar belum dimanfaatkan, melainkan hanya dibakar atau dibiarkan jadi tumpukan limbah yang menimbulkan berbagai dampak lingkungan dan gangguan sekitar perkebunan (Rachmawati et al., 2018a).

Tahun 2017 luas lahan perkebunan sawit di Indonesia sedikitnya 11 juta hektar. Selain menunjukkan prospek hasil minyak nabati yang berlimpah, luasan kebun sawit ini memicu kekhawatiran melimpahnya batang sawit saat regenerasi kebun dilakukan. Jika 4 persen dari luasan itu direplanting/peremajaan tiap tahun, ada hampir 100 juta kubik batang sawit akan teronggok menjadi sampah. Pengelola kebun sering membiarkan batang sawit membusuk. Selain menimbulkan bau tidak enak, pelapukan alami membuat batang sawit menjadi sarang kumbang Oryctes rhinoceros dan jamur Ganoderma. Hal ini akan mengganggu tanaman sawit muda dan merugikan kebun dan bisa juga menyebabkan kebakaran hutan yaitu dengan melepas emisi karbon ke atmosfer. Cara lain, yaitu membakar batang sawit (Rachmawati et al., 2018b). Namun, hal ini dilarang Undang-Undang karena membahayakan.

Dengan potensi yang sedemikian besar, teknologi yang tepat menjadi suatu kebutuhan yang tidak dapat dielakkan untuk pemanfaatan limbah kayu hasil replanting / peremajaan tersebut. Batang kelapa sawit justru menekan laju deforestasi dan bisa diolah menjadi berbagai komoditas bernilai tinggi. Limbah kayu juga dapat dimanfaatkan sebagai bahan baku pengganti kayu hutan yang biasa digunakan untuk meubel (furniture), bahan baku asesoris interior, dan bahan baku produk kerajinan dan memberi tambahan penghasilan bagi yang kebunnya diremajakan. Jika tidak dapat memanfaatkan langsung bahan tersebut, setidaknya, petani masih bisa mendapatkan tambahan penghasilan dari penjualan batang sawit.

Tujuan penelitian adalah pengawetan batang kelapa sawit hasil replanting / peremajaan menggunakan natrium tetra boraks dan melihat kemampuan dari natrium tetra boraks untuk meningkatkan kekuatan kayu batang kelapa sawit hasil replanting dengan memvariasikan konsentrasi natrium tetra boraks dan lama waktu perendaman kayu batang sawit di dalam cairan natrium tetra boraks .

\section{Metode}

Pohon sawit untuk penelitian ini adalah Verietas Dura yang diambil di area Perkebunan PT. Bakri Pasaman Plantation Jorong Tanjung Babolik, Kanagarian Sungai Aur, Kecamatan Sungai Aur, Kabupaten Pasaman Barat. Tanaman sawit ini ditanam tahun 1992 dan mengalami replanting tahun 2019. Alat yang digunakan mesin gergaji, gergaji, mesin penyerut, dan baskom besar. Bahan kimia yang digunakan adalah natrium tetra boraks $\left(\mathrm{Na}_{2} \mathrm{~B}_{3} \mathrm{O}_{4}\right)$, lem PVAC, lem Dextone, Cyanocrylate, Biovernis dan Melamin.

Batang kelapa sawit dipotong dengan ukuran panjang 1,5 $\mathrm{m}$, lalu dibelah dengan memakai mesin gergaji band rcsaw (BS - 44"). Kayu bagian luar setebal $10 \mathrm{~cm}$ dan bagian dalam tebal $10 \mathrm{~cm}$ dipisahkan potongannya. Setelah itu dikering anginkan dengan cara menyusunnya secara stic sampai 30 hari sehingga mencapai kadar air kering udara $30 \%$.

Penelitian dilakukan dengan memvariasikan jenis bagian batang, konsentrasi bahan pengawet, dan waktu perendaman. Jenis bagian batang yang digunakan adalah batang bagian luar dan batang bagian dalam. Tiga level konsentrasi natrium tetra boraks yaitu $1 \%, 2,5 \%$, dan $5 \%$. Waktu perendaman yang dilakukan adalah 2 hari, 4 
hari, dan 6 hari. Skema penelitian seperti ditampilkan pada Gambar 1.

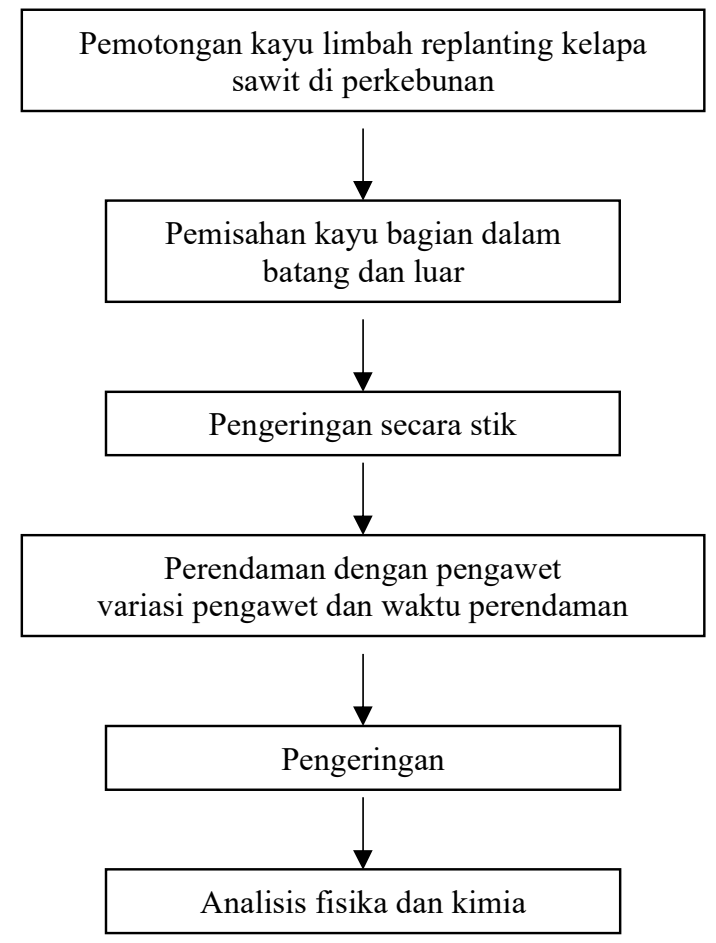

Gambar 1. Skema pengawetan

\section{Pengujian}

Pengamatan dilakukan setelah proses pengawetan dan pengeringan. Pengujian yang dilakukan meliputi kadar air, kerapatan, kuat tekan, dan kuat lentur. Pengolahan data ditampilkan dari rata-rata hasil pengujian yang didapat berupa grafik.

\section{Kadar air}

Contoh uji kadar air berukuran $5 \mathrm{~cm}$ x $5 \mathrm{~cm}$ x $10 \mathrm{~cm}$ ditimbang untuk menentukan berat awalnya, lalu dimasukkan ke dalam oven dengan suhu $103 \pm 2{ }^{\circ} \mathrm{C}$ selama 24 jam. Setelah itu contoh uji ditimbang beratnya hingga konstan. Menurut (Harsono, 2016) kadar air kayu didapat dari perbandingan jumlah (berat) kayu kering udara dibandingkan berat kayu kering yang dinyatakan dalam persen (\%) seperti persamaan 1 .

Kadar air $=\frac{B D \quad B K}{B K} \times 100 \%$

Keterangan :

$\mathrm{BB}=$ Berat kayu awal

$\mathrm{BK}=$ Berat kayu kering

\section{Kerapatan}

Contoh uji berukuran $5 \mathrm{~cm}$ x $5 \mathrm{~cm}$ x $10 \mathrm{~cm}$ ditimbang dan diukur dimensi awalnya (volume), lalu dimasukkan ke dalam oven dengan suhu $103 \pm 2^{\circ} \mathrm{C}$ selama 24 jam. Setelah itu contoh uji ditimbang dan diukur kembali dimensinya seperti persamaan (2).
Kerapatan $\left(\frac{g}{\mathrm{~cm}^{2}}\right)=\left(\frac{\text { Berat kering }}{\text { Volume Basah }}\right)$

Keterangan :

Berat kering $=$ Berat Kayu $(\mathrm{g})$

Volume basah $=$ Volume sebelum di oven $\left(\mathrm{cm}^{3}\right)$

\section{Sifat mekanik \\ Kuat tekan}

Kuat tekan adalah besarnya beban persatuan luas yang menyebabkan benda uji hancur bila dibebani dengan gaya tekan tertentu, yang dihasilkan dari alat Universal Testing Machine (UTM). Menurut (Iswanto et al., 2010) kuat tekan dapat dihitung melalui persamaan 3 .

$$
\text { Kuat Tekan }(\mathrm{P})=\frac{F}{A}
$$

Keterangan :

$\mathrm{F}=$ Gaya Tekan $(\mathrm{N})$

$\mathrm{A}=$ Luas Penampang $\left(\mathrm{m}^{2}\right)$

Jika gaya tekan $\mathrm{F}=1 \mathrm{~N}$ bekerja pada luas permukaan $\mathrm{A}$ $=1 \mathrm{~m}^{2}$, maka menurut persamaan di atas kuat tekan adalah seperti persamaan 4 .

$$
P=\frac{F}{A}=\frac{1 N}{1 n^{2}}=1 N / m^{2}
$$

Untuk pengukuran diperlukan mesin kuat tekan, mistar/rol meter, kayu ukuran $10 \mathrm{~cm} \times 10 \mathrm{~cm} \times 5 \mathrm{~cm}$. Alat yang digunakan untuk uji kuat tekan Merk Wekob seri 2153 buatan German.

Tahapan pengujian diawali dengan menghidupkan mesin dan dibiarkan beberapa waktu untuk pemanasan. Sebelum dilakukan pengujian setiap benda uji kayu diberi nomor kode lalu diukur lebar dan panjangnya. Benda uji kemudian dempatkan pada mesin kuat tekan. Mesin kuat tekan lalu dijalankan dengan memberikan tekanan pada benda uji. Baca kuat tekan pada alat apabila kayu telah pecah.

\section{Kuat lentur}

Alat yang digunakan untuk uji kuat lentur Merk Wekob seri 2153 buatan German. Tahapan pengujian dimulai dengan menyiapkan benda uji dengan ukuran kayu $5 \times 5 \times 76 \mathrm{~cm}$. Mesin alat kuat lentur dihidupkan dan dibiarkan beberapa waktu untuk pemanasan. Setiap jenis kayu dalam setiap pengujian diberi nomor kode dan sebelum dipasang pada alat uji diukur lebar dan tinggi beda ujinya. Benda uji ditempatkan pada alat dengan peletakan jarak tumpu $70 \mathrm{~cm}$. Berikan beban kuat lentur pada tengah-tengah kayu. Baca kuat lentur apabila kayu sudah mengalami patah atau pecah dan tidak mampu dibebani lagi.

Besarnya kuat lentur menurut (Fatori M, 2013) dapat dihitung melalui persamaan (5).

Kuat lentur $=3 \mathrm{PL} / 2 \mathrm{BH}$ 
Keterangan :

$\mathrm{P}=$ Beban patah

$\mathrm{L}=$ Jarak tumpuan

$\mathrm{B}=$ Lebar benda uji

$\mathrm{H}=$ Tinggi benda uji

\section{Hasil dan pembahasan \\ 3.1. Kadar air}

Berdasarkan nilai rata-rata kadar air batang kelapa sawit hasil replanting / peremajaan yang telah dikeringkan beberapa hari sebelum dilakukan pengawetan rata-rata $35,1 \%$ untuk bagian dalam dan $25,5 \%$ untuk bagian luar. Kadar air kayu bagian dalam berada di atas kadar air titik jenuh serat $(<30 \%)$, sehingga bahan pengawet agak sulit masuk kedalam serat kayu. Kayu bagian luar memiliki nilai kadar air di bawah kadar air titik jenuh serat kayu $(<30 \%)$ sehingga bahan pengawet menjadi lebih mudah masuk kedalam serat kayu.

Kadar kayu dibawah titik jenuh serat ditandai dengan berkurangnya kandungan air dalam dinding sel sehingga bahan pengawet lebih mudah masuk kedalam ronggarongga sel kayu yang kosong. Sebaliknya bila nilai kadar kayu diatas titik jenuh serat maka proses perendaman bahan pengawet akan susah karena adanya kandungan air yang masih mengisi dalam rongga sel. Hal tersebut menunjukkan kadar air merupakan salah satu faktor penting pada proses penembusan bahan pengawet kedalam kayu.

Menurut (Djoko, 2009) faktor yang mempengaruhi kadar air kayu yaitu suhu, kelembaban, dan jenis kayu. Apabila rongga-rongga sel banyak mengandung air maka bahan pengawet akan terhalang dan sulit masuk kedalam kayu. Apabila kandungan air dalam kayu masih tinggi maka bahan pengawet yang masuk ke dalam kayu semakin sedikit karena rongga-rongga sel terhalang oleh kadar air.

Sebaliknya apabila kandungan air dalam rongga sel telah keluar atau sedikit maka bahan pengawet akan mudah masuk ke dalam kayu. Menurut (Salmayanti et al., 2013) kadar air optimum bagi pengawet akan berbeda-beda untuk setiap jenis kayu, jenis bahan pengawet dan metode pengawet yang diberikan. Apabila kandungan kadar air dalam kayu tinggi maka bahan pengawet yang akan masuk kedalam kayu semakin kecil.

Setelah dilakukan pengawetan dengan $\mathrm{Na}_{2} \mathrm{~B}_{3} \mathrm{O}_{4}$ dengan perendaman selama 2 hari, 4 hari, dan 6 hari, kayu dikeringkan. Proses pengeringan akan menurunkan kadar air bila dibandingkan sebelum dilakukan pengawetan. Pada Gambar 2 dapat dilihat setelah perendaman selama 2 hari dan dikering anginkan didapat kadar air kayu bagian dalam masing masing 13,72\%, $15,40 \%$, dan 18,34 \% untuk konsentrasi 1; 2,5; dan 5\%. Kadar air rata-rata kayu bagian dalam adalah 15,82\%. Kadar air kayu bagian luar adalah 16,27\%, 13,11\%, dan $14,1 \%$. Kadar air rata-rata kayu bagian luar yaitu $14,49 \%$, lebih kecil dibandingkan kayu bagian dalam.

Perendaman 4 hari (Gambar 3) didapat kadar air kayu bagian dalam yaitu $10,54 \%, 10,41 \%$, dan $11,11 \%$ dan kayu bagian luar yaitu 8,52\%, 8,25\%, dan $10,5 \%$ berturut-turut untuk masing-masing konsentrasi 1; 2,5; dan 5\%. Sedangkan untuk perlakuan 6 hari (Gambar 4) diperoleh kadar air kayu bagian dalam 13,89\%, 13,42\% dan $12,31 \%$ dengan rata-rata kadar air 13,20\%. Kayu bagian luar memiliki kadar air berturut turut 10,55\%, $10,66 \%$, dan $10,70 \%$ dengan rata rata kadar air $10,62 \%$.

Kadar air rata-rata kayu bagian luar lebih rendah dibandingkan dengan kayu bagian dalam.

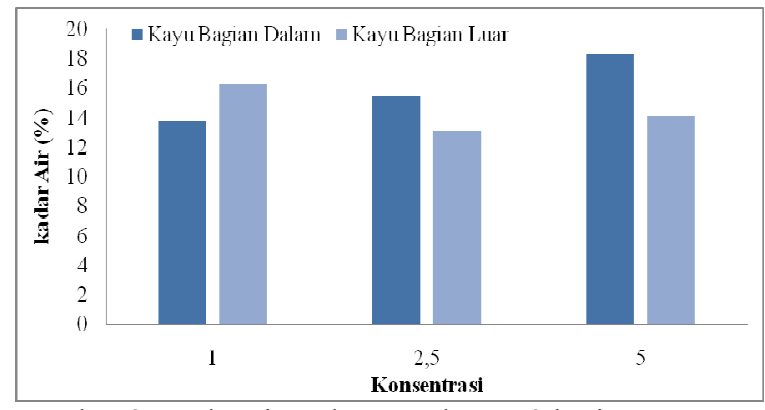

Gambar 2. Kadar air pada perendaman 2 hari

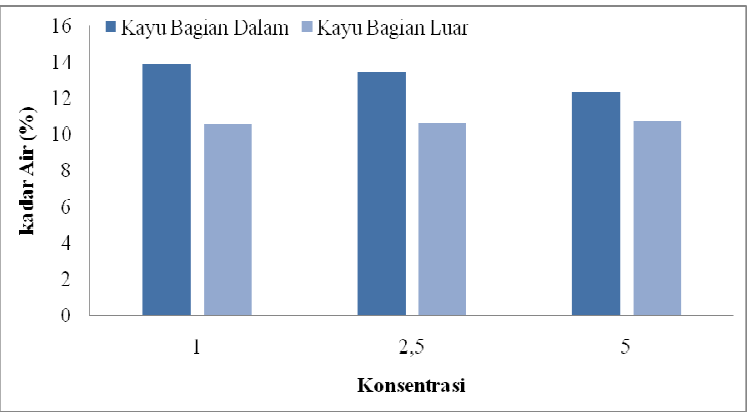

Gambar 3. Kadar air pada perendaman 4 hari

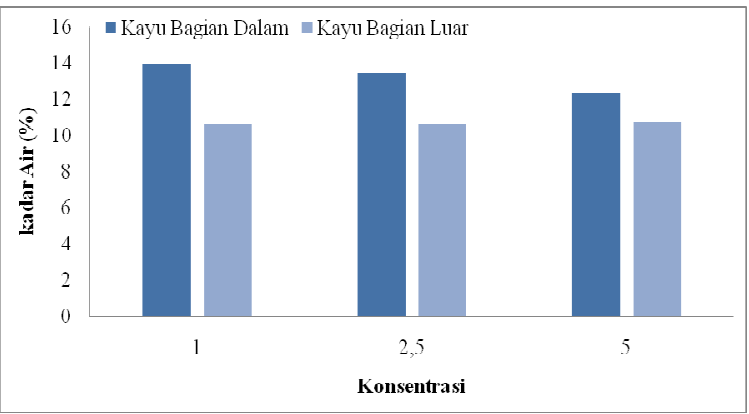

Gambar 4. Kadar air pada perendaman 6 hari

Kadar air yang paling rendah adalah adalah kayu bagian luar pada perlakuan perendaman 4 hari dengan kosentrasi $\mathrm{Na}_{2} \mathrm{~B}_{3} \mathrm{O}_{4} \quad 2,5 \%$. Dengan penambahan kosentrasi pengawet dan perendaman 4 hari, kadar air semakin rendah. Hal ini dikarenakan koponen dari natrium tetra boraks dapat dengan mudah masuk kedalam rongga sel kayu yang kosong (Roihan et al., 2015). Ketika direndam dalam bahan pengawet akan terjadi peningkatan kadar air kayu, namun sebagian besar air ini akan menguap pada proses pengeringan. Kadar air sangat ditentukan pada proses pengeringan yang dilkakukan. Rata-rata kadar air kayu memenuhi standar kondisi kayu sesuai SNI 7973:2013 tentang spesifikasi desain untuk konstruksi kayu, dimana kadar air tidak melebihi $19 \%$.

http://dx.doi.org/10.24960/jli.v11i1.6981.59-66 


\subsection{Kuat tekan}

Kuat tekan kayu adalah kekuatan kayu untuk menahan muatan jika kayu itu digunakan untuk tujuan tertentu. Kuat tekan mempunyai hubungan dengan kekerasan kayu dan keteguhan geser. Dari hasil pengujian batang kelapa sawit didapatkan kuat tekan sebelum kayu dilakukan pengawetan adalah $3,73 \mathrm{~kg} / \mathrm{cm}^{2}$ untuk kayu bagian dalam dan $5,47 \mathrm{~kg} / \mathrm{cm}^{2}$ untuk kayu bagian luar. Berdasarkan Peraturan Konstruksi Kayu Indonesia (PKKI) kayu tersebut termasuk kayu kelas V yaitu berada pada kayu dengan kuat tekan pada skala $\leq$ $215 \mathrm{~kg} / \mathrm{cm}^{2}$ sebagai kayu kelas V (Departemen pekerjaan umum, 1961).

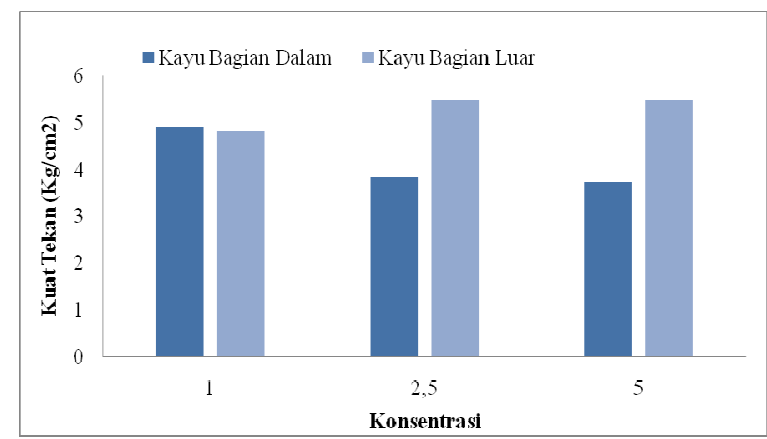

Gambar 5. Kuat tekan pada perendaman 2 hari

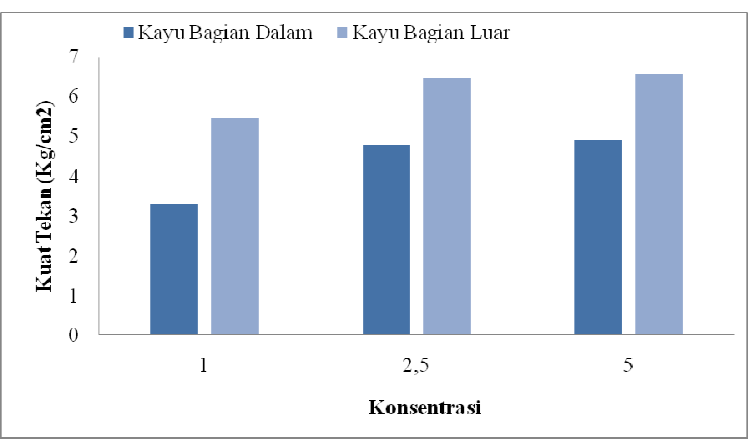

Gambar 6. Kuat tekan pada perendaman 4 hari

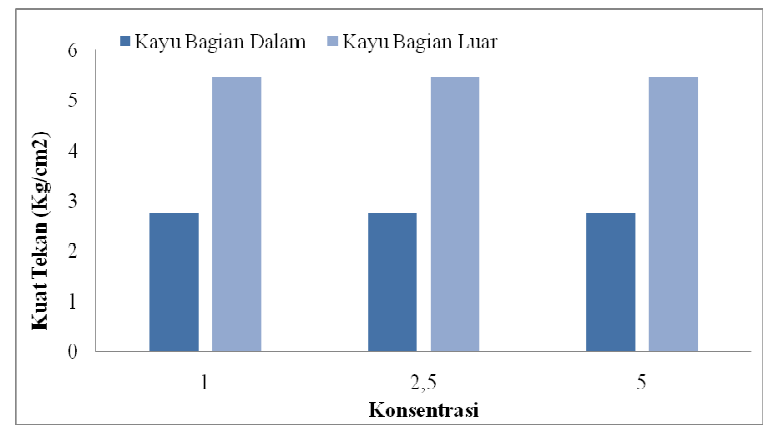

Gambar 7. Kuat tekan pada perendaman 6 hari

Setelah dilakukan pengawetan dengan $\mathrm{Na}_{2} \mathrm{~B}_{3} \mathrm{O}_{4}$ selama 2 hari (Gambar 5) terlihat kayu bagian dalam memiliki kuat tekan sebesar 3,73-4,91 kg/ $\mathrm{cm}^{2}$, sedangkan kayu bagian luar sebesar 4,82-5,47 kg/ $\mathrm{cm}^{2}$. Perlakuan perendaman 2 hari tidak memberikan pengaruh yang nyata terhadap peningkatan kuat tekan kayu, baik bagian dalam dan luar untuk semua variasi konsentrasi.
Perlakuan perendaman 4 hari menghasilkan kayu dengan kuat tekan sebesar 3,28-4,91 kg/cm ${ }^{2}$ untuk bagian dalam dan bagian luar sebesar $5,47-6,56 \mathrm{~kg} / \mathrm{cm}^{2}$. Terjadi peningkatan kuat tekan bila dibandingkan dengan perendaman 2 hari. Hal ini disebabkan pada perendaman 4 hari pengawet sempurna masuk ke seratserat kayu dan bisa menjadi perekat pada kayu dan akhirnya bisa meningkatkan kuat tekan kayu. Bila dibandingkan dengan kayu tanpa pengawetan, maka terjadi peningkatan kuat tekan sebesar $1,18 \mathrm{~kg} / \mathrm{cm}^{2}$ untuk kayu bagian dalam dan $1,09 \mathrm{~kg} / \mathrm{cm}^{2}$ untuk kayu bagian luar.

Peningkatan konsentrasi pengawet memberikan pengaruh terhadap kuat tekan kayu. Terjadi sedikit peningkatan kuat tekan dengan meningkatnya konsentrasi $\mathrm{Na}_{2} \mathrm{~B}_{3} \mathrm{O}_{4}$, baik kayu bagian dalam dan luar. Peningkatan kuat tekan pada kayu batang sawit karena adanya ikatan rekat antara melekul larutan $\mathrm{Na}_{2} \mathrm{~B}_{3} \mathrm{O}_{4}$ dan komponen selulosa pada kayu batang sawit yang berkerapatan rendah diduga bahan pengawet $\mathrm{Na}_{2} \mathrm{~B}_{3} \mathrm{O}_{4}$ lebih banyak berpenetrasi dan membentuk rantai ikatan yang lebih kuat sehingga dapat meningkatkan kekuatan kayu batang sawit (Santoso et al., 2016).

Kuat tekan kayu pada perendaman 6 hari (Gambar 7) diperoleh rata-rata $2,74 \mathrm{~km} / \mathrm{cm}^{2}$ untuk kayu bahagian dalam terjadi penurunan dibandingkan dengan kayu sebelum pengawetan. Kuat tekan kayu bahagian luar $5,74 \mathrm{~km} / \mathrm{cm}^{2}$, nilai ini sama dengan kuat tekan sebelum pengawetan. Terjadinya penurunan kuat tekan pada perendaman 6 hari disebabkan terjadinya pengaraman pada kayu. Hal ini dapat menyebabkan kayu turun kualitasnya dan menjadi rendah kuat tekannya.

\subsection{Kuat lentur}

Kuat lentur adalah kemampuan kayu untuk menahan kekuatan dari luar. Kekuatan dari luar adalah gaya-gaya di luar benda yang mempunyai kecenderungan untuk mengubah benda dan besarannya benda. Hakekatnya hampir pada semua penggunaan kayu dibutuhkan syarat kekuatan keteguhan tekan dan keteguhan lentur (lengkung). Keteguhan lentur kayu adalah kemampuan kayu untuk melengkungkan diri ketika menahan tekanan dari atasnya. Menurut (Harsono, 2016), kuat lentur ialah kekuatan untuk menahan gaya-gaya yang berusaha melengkungkan kayu atau menahan beban mati maupun hidup, selain beban pukulan yang harus dipikul oleh kayu tersebut.

Pengujian awal kuat lentur sebelum perlakuan pengawetan kayu bagian dalam didapatkan $26,48 \mathrm{~kg} / \mathrm{cm}^{2}$ dan kayu bagian luar $32,16 \mathrm{~kg} / \mathrm{cm}^{2}$. Kuat lentur kayu bagian luar lebih besar dari kayu bagian dalam. Hal ini disebabkan pengaruh kadar air kayu bagian dalam lebih besar dari kayu bagian luar dan juga pengaruh kerapatan kayu, dimana kerapatan kayu bagian luar lebih tinggi dibandingkan kayu bagian dalam. Dari hasil pengujian menunjukkan kekuatan lentur kayu limbah replanting kelapa sawit termasuk rendah bila dibandingkan dengan kelas kayu berdasarkan PPKI 1961 yaitu digolongkan kelas V dengan kuat lentur kecil dari $300 \mathrm{~kg} / \mathrm{cm}^{2}$.

Perlakuan perendaman selama 2 hari seperti pada Gambar 8 diperoleh kuat lentur kayu bagian dalam $20,76-28,21 \mathrm{~kg} / \mathrm{cm}^{2}$ dan kayu bagian luar 36,84-44,68 
$\mathrm{kg} / \mathrm{cm}^{2}$. Bila dibandingkan dengan kayu tanpa perlakuan pengawet terjadi peningkatan kuat lentur kayu. Perlakuan perendaman 4 hari (Gambar 9) diperoleh kuat lentur kayu bagian dalam 26,47-30,64 kg/ $\mathrm{cm}^{2}$ dan kayu bagian luar $43,88-47,19 \mathrm{~kg} / \mathrm{cm}^{2}$. Jika dibandingkan dengan perlakuan perendaman 2 hari, maka perendaman 4 hari memiliki kuat lentur yang lebih tinggi.

Kuat lentur perlakuan perendaman 6 hari (Gambar 10) adalah $19,87-24,84 \mathrm{~kg} / \mathrm{cm}^{2}$ untuk kayu bagian dalam dan $36,47-44,71 \mathrm{~kg} / \mathrm{cm}^{2}$ untuk kayu bagian luar. Kuat lentur perlakuan perendaman 6 hari bila dibandingkan dengan perlakuan 4 hari terjadi penurunan kuat lentur baik kayu bagian dalam maupun bagian luar. Hal ini disebabkan terjadinya penggaraman setelah dilakukan perendaman dengan pengawet selama 6 hari. Penggaraman akan menyebabkan kayu akan lebih lunak dan mudah patah.

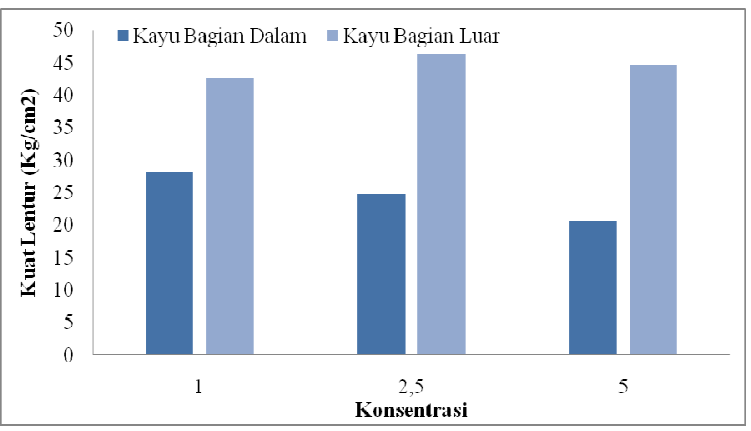

Gambar 8. Kuat lentur pada perendaman 2 hari

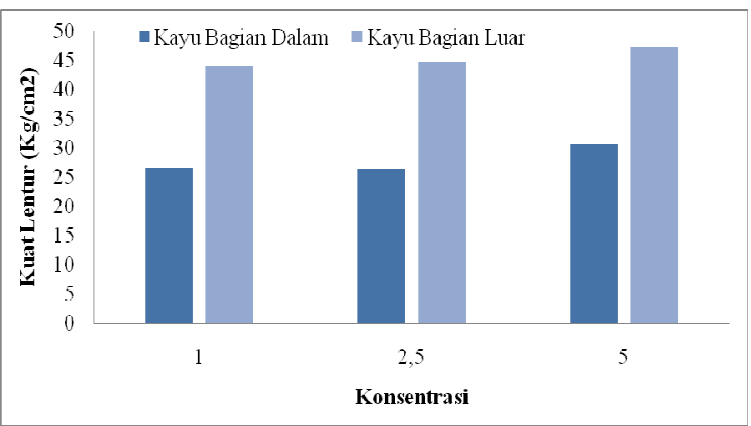

Gambar 9. Kuat lentur pada perendaman 4 hari

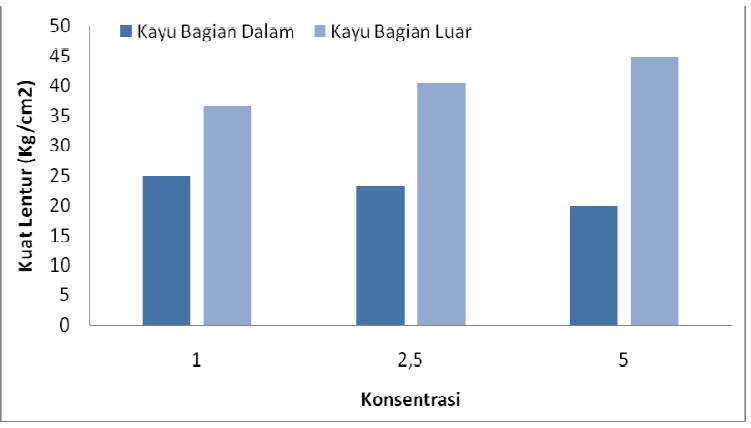

Gambar 10. Kuat lentur pada perendaman 6 hari

\subsection{Kerapatan}

Hasil kerapatan awal menunjukkan bahwa nilai kerapatan kayu bagian dalam $0,19 \mathrm{~g} / \mathrm{cm}^{3}$ dan kayu bagian luar $0,25 \mathrm{~g} / \mathrm{cm}^{3}$. Kayu bagian luar memiliki nilai kerapatan yang lebih besar dibandingkan dengan kayu bagian dalam. Kerapatan kayu batang kelapa sawit termasuk ke dalam kelas kerapatan rendah. Hal ini sesuai dengan yang dikemukakan oleh (Darwis et al., 2014) bahwa sifat fisik dan mekanis serta keawetan kayu kelapa sawit rendah.

Kayu yang memiliki nilai kerapatan rendah masuk ke dalam kelompok kayu yang mudah menyerap bahan pengawet. Nilai kerapatan kayu yang masuk kategori rendah pada dasarnya memiliki pembuluh yang terbuka dan besar sehingga kemampuan untuk menyerap bahan pengawet akan lebih baik dibandingkan dengan kayu dengan kategori kerapatan yang tinggi (Indahsuary Uar et al., 2018). Kerapatan kayu ikut berpengaruh terhadap penyerapan bahan pengawet dan sangat tergantung pada air serta bahan penyusun di dalam dinding sel. Oleh karena itu, jika kayu telah mencapai kondisi kering udara (12-18\%), maka nilai kerapatannya menunjukkan perkiraan banyaknya rongga-rongga sel yang dimungkinkan untuk diisi oleh bahan pengawet. Pada proses pengawetan, bahan pengawet yang larut air lebih mudah masuk ke dalam dinding sel.

Setelah dilakukan pengawetan untuk perlakuan perendaman selama 2 hari (Gambar 11) diperoleh kerapatan kayu bagian dalam $0,15-0,25 \mathrm{~g} / \mathrm{cm}^{3}$ dan kayu bagian luar 0,26-0,29 $\mathrm{g} / \mathrm{cm}^{3}$. Bila dibandingkan dengan kayu tanpa perlakuan terjadi peningkatan kerapatan, baik kayu bagian dalam dan kayu bagian luar. Untuk perlakuan perendaman 4 hari pada Gambar 12, kerapatan kayu bagian dalam didapat $0,21-0,24 \mathrm{~g} / \mathrm{cm}^{3}$ dan kayu bagian luar antara 0,26-0,30 $\mathrm{g} / \mathrm{cm}^{3}$. Jika dibandingkan dengan perlakuan perendaman 2 hari, kayu dengan perendaman 4 hari memiliki kerapatan rata-rata yang lebih tinggi, hal ini terjadi dengan adanya sifat dari natrium tetra boraks yang banyak digunakan sebagai bahan pengawet dan pengenyal yang akan dapat menutupi pori-pori dari kayu batang kelapa sawit dan dapat meningkatkan kerapatan (Nurjaya, 2013)

Pada perendaman dengan waktu 6 hari (Gambar 13), kayu bagian dalam memiliki kerapatan $0,14-0,17 \mathrm{~g} / \mathrm{cm}^{3}$ dan kayu bagian luar 0,22-0,25 $\mathrm{g} / \mathrm{cm}^{3}$. Terjadi penurunan kerapatan, baik kayu bagian dalam maupun bagian luar pada perendaman 6 hari dibandingkan 4 hari. hal ini disebabkan terjadinya penggaraman setelah dilakukan perendaman dengan pengawet selama 6 hari. Dengan terjadinya penggaraman, maka akan lebih banyak timbul pori pada kayu. Menurut (Indahsuary Uar et al., 2018), kerapatan juga dipengaruhi oleh banyaknya pori dalam kayu, semakin banyak pori pada kayu semakin kecil kerapatan.

Pengawetan dengan memakai $\mathrm{Na}_{2} \mathrm{~B}_{3} \mathrm{O}_{4}$ dengan variasi kosentrasi dan waktu perendaman seperti pada Gambar 11, 12 dan 13 mempengaruhi kerapatan kayu terutama kayu bagian luar. Kayu yang memiliki kerapatan yang tertinggi adalah bagian luar pada perlakuan dengan kosentrasi $\mathrm{Na}_{2} \mathrm{~B}_{3} \mathrm{O}_{4} 2,5 \%$ dan waktu perendaman 4 hari. Kayu dengan kerapatan paling rendah adalah bagian dalam pada perlakuan dengan kosentrasi $\mathrm{Na}_{2} \mathrm{~B}_{3} \mathrm{O}_{4} 2,5 \%$ dan waktu perendaman 2 hari. 


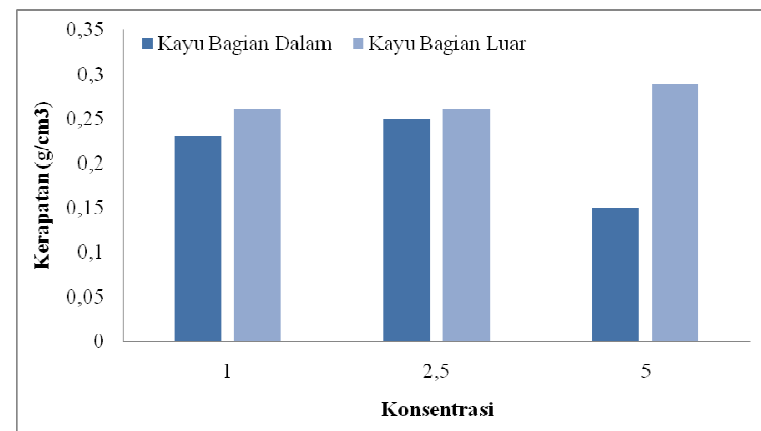

Gambar 11. Kerapatan pada perendaman 2 hari

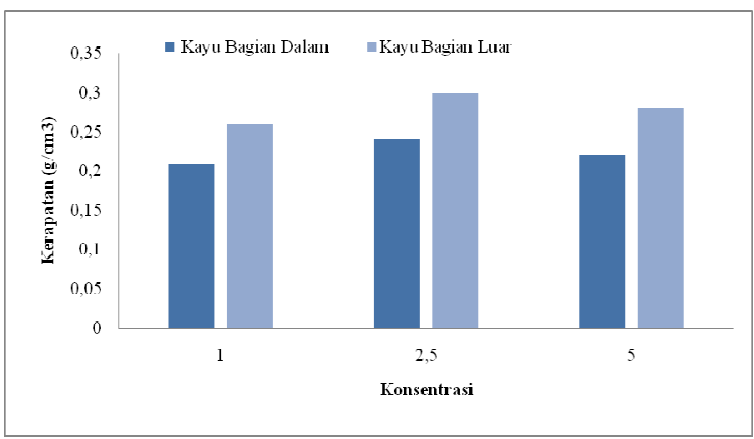

Gambar 12. Kerapatan pada perendaman 4 hari

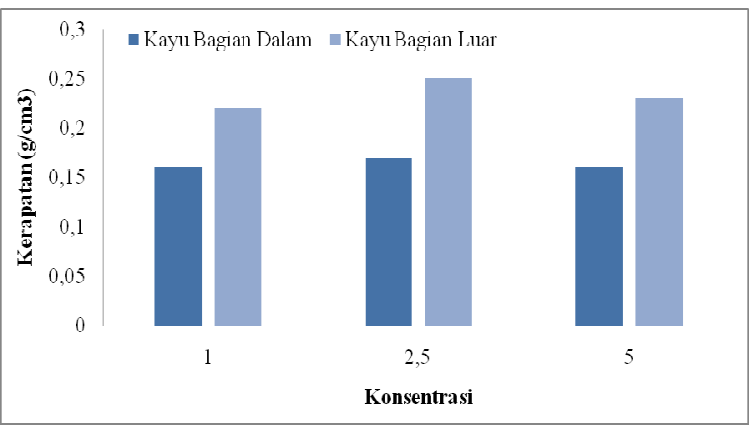

Gambar 13. Kerapatan pada perendaman 6 hari

\subsection{Produk dari limbah kayu kelapa sawit hasil pengawetan}

Kayu hasil pengawetan memiliki sifat yang memenuhi syarat untuk dibuat menjadi produk-produk meubel. Kayu yang diperoleh dari hasil penelitian ini dibuat menjadi beberapa produk seperti meja komputer dan lemari seperti yang disajikan pada Gambar 14, 15, dan 16.
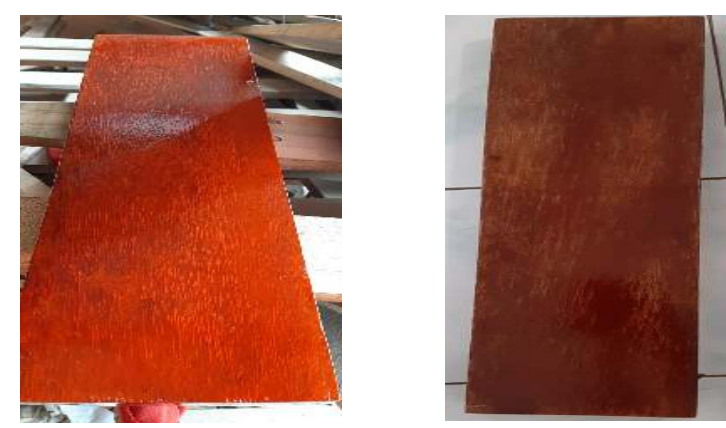

Gambar 14. Papan dari kayu hasil pengawetan

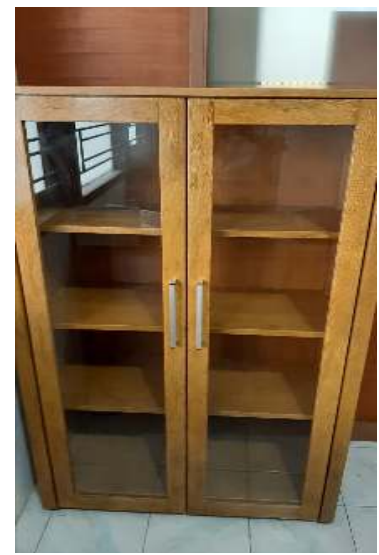

Gambar 15. Lemari yang dibuat dari kayu hasil pengawetan

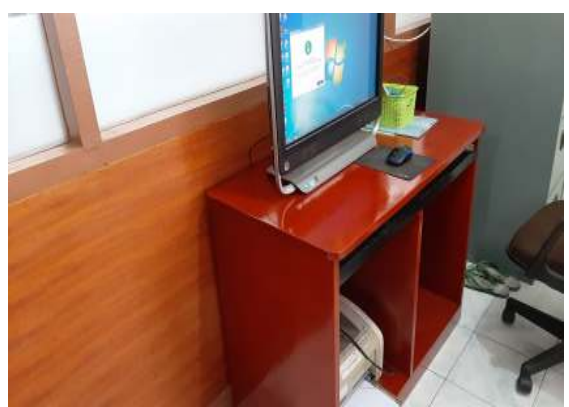

Gambar 16. Meja komputer yang dibuat dari kayu hasil pengawetan

\section{Kesimpulan}

Hasil penelitian setelah proses pengawetan dengan memvariasikan kosentrasi pengawet $\mathrm{Na}_{2} \mathrm{~B}_{3} \mathrm{O}_{4}$ dan variasi waktu perendaman dapat meningkatkan sifat kimia dan sifat fisis kayu batang sawit hasil replanting. Bila dibandingkan dengan kayu tanpa perlakuan, terjadi peningkatan sifat kerapatan, kuat lentur, dan kuat tekan kayu, dimana kayu bagian luar memiliki kuat tekan, kuat lentur, dan kerapatan lebih tinggi dari pada kayu bagian dalam. Perlakuan terbaik diperoleh menggunakan kayu bagian luar dengan waktu perendaman selama 4 hari dan kosentrasi pengawet $\mathrm{Na}_{2} \mathrm{~B}_{3} \mathrm{O}_{4} 2,5 \%$. Hal ini ditunjukkan dari hasil analisis dimana terjadi peningkatan kuat lentur, kuat tekan, kerapatan, dan penurunan kadar air setelah proses pengeringan. Kayu yang dihasilkan dari pengawetan dengan $\mathrm{Na}_{2} \mathrm{~B}_{3} \mathrm{O}_{4}$ memiliki sifat yang cukup baik untuk dibuat menjadi produk-produk asesoris dan meubel.

\section{Daftar pustaka}

Darwis, A., Massijaya, M.Y., Nugroho, N., Alamsyah, E.M., 2014. Karakteristik papan laminasi dari batang kelapa sawit (The Characteristics of the laminated board of oil palm trunk). J. Ilmu Teknol. kayu Trop. 157-168.

Departemen pekerjaan umum, 1961. Peraturan kontruksi kayu -ni-5-pkki-1961.pdf.

Djoko, P., 2009. Pengaruh pengeringan alami dan buatan terhadap kualitas kayu galam untuk bahan mebel. J. Ris. Has. hutan 1, 1-7. 
Fatori M, 2013. Teknologi bahan furniture. Kemendikbut, Jakarta.

Harsono, D., 2016. Efektifitas pengawetan batang kelapa sawit (Elaeis guinensis Jacq.) terhadap serangan rayap tanah (Coptotermes curvignathus holmgren) menggunakan campuran boraks dan asam borat. J. Ris. Has. hutan 1998, 87-98.

Indahsuary Uar, N., Wali, M., Tuharea, M, S., 2018. Sifat fisis kayu marsegu (Nauclea orientalis L) dari Pulau Buru, Maluku. J. Agrohut, Fak Pertan. Univ. Darussalam Ambon Vol 9 No 2, 110-116.

Iswanto, A. heri, Sucipto, T., Azhar, I., Coto, Z., Febrianto, F., 2010. Sifat fisis dan mekanis batang kelapa sawit (Elaeis guineensis Jacq) asal kebun Aek Pancur Sumatera Utara. J. ilmu dan Tehnol. Has. hutan Vol 3 No 1, 1-7.

Kamal, N., 2012. Karakteristik dan potensi pemanfaatan limbah sawit. itenas Libr. 61-68.

Nurjaya, A., 2013. Pengaruh pemberian boraks dosis bertingkat terhadap perubahan gambaran makroskopis dan mikroskopis hapar. Semarang.

Perkebunan, D.J., 2017. Statistik perkebunan Indonesia 2016-2018 kelapa sawit. Jakarta.

Rachmawati, O., Sugita, P., Santoso, A., 2018a. Peningkatan kualitas kayu sawit dengan perlakuan kompregnasi menggunakan tanin resorsinol formaldehida. J. Penelit. Has. hutan 36, 181-190.

Rachmawati, O., Sugita, P., Santoso, A., 2018b. Sintesis perekat tanin resosinol formaldehida dari eksrak kulit pohon margium untuk peningkatan kualitas batang sawit. J. Penelit. Has. hutan 46, 33-46. https://doi.org/10.20886/jphh.2018.36.1.33-46

Roihan, A., Hartono, R., Sucipto, T., 2015. Kualitas papan partikel dari komposisi partikel batang kelapa sawit dan mahoni dengan berbagai variasi kadar perekat phenol formaldehida (Quality of composition particle board of oil palm trunk and mahogany particle with various levels variations Phe. Peronema For. Sci. 1-9.

Salmayanti, S., Ariyanti, A., Hafid, A., 2013. Pengaruh konsentrasi dan lama perendaman bahan pengawet daun tembelekan (Lantana camara L) pada kayu bayur terhadap serangan rayap tanah. J. War. Rimba $1,1-8$.

Santoso, A., Sulastiningsih, I.M., Pari, Gustan, . \& Jusni, 2016. Pemanfaatan eksrak kayu merbau untuk perekat produk laminasi bambu. J. Penelit. Has. hutan Vol 34. https://doi.org/10.20886/jphh. 2016.34.2.89-100

Siregar, M.S., 2011. Penguatan sifat mekanik kayu kelapa sawit dengan teknik impregnasi reaktif monometer stirena. J. Agrium 16, 147-152. 